\title{
Description of a new species of Perichaena (Myxomycetes) from arid areas of Argentina
}

\author{
by \\ ${ }^{1}$ Carlos Lado, ${ }^{1}$ Diana Wrigley de Basanta, ${ }^{2}$ Arturo Estrada-Torres, ${ }^{1}$ Eva García Carvajal, \\ ${ }^{1}$ María Aguilar \& ${ }^{1}$ Juan Carlos Hernández-Crespo \\ ${ }^{1}$ Real Jardín Botánico, CSIC, Plaza de Murillo 2, E-28014 Madrid, Spain. lado@rjb.csic.es \\ ${ }^{2}$ Centro de Investigación en Ciencias Biológicas, Universidad Autónoma de Tlaxcala, km 10,5 \\ carretera Texmelucan-Tlaxcala, Ixtacuixtla, 90122, Tlaxcala, México. arturomixo@hotmail.com
}

\begin{abstract}
Lado, C., Wrigley de Basanta, D., Estrada-Torres, A., García Carvajal, E., Aguilar, M. \& Hernández-Crespo, J.C. 2009. Description of a new species of Perichaena (Myxomycetes) from arid areas of Argentina. Anales Jard. Bot. Madrid 66S1: 63-70.

A new species of the myxomycete genus Perichaena is described in this paper. The new species, named Perichaena calongei, was found during intensive studies of arid areas of the Monte desert in Argentina. It has been found directly in the field from the provinces of Catamarca, La Rioja, Salta and San Juan, in the Northwest of Argentina, and isolated from moist chamber cultures of native plant species collected in Catamarca, Jujuy, Salta and San Juan. The characters that make this species unique in the genus are the combination of the morphology of the sporocarps, the structure and dehiscence of the peridium, and the ornamentation of the capillitium. The morphology of the myxomycete specimens was examined using light microscopy with Nomarski interference contrast, and scanning electron microscopy. Micrographs of relevant morphological characters are included. A key to facilitate the identification of the stipitate species of Perichaena is also proposed.
\end{abstract}

Keywords: Monte desert, morphogenesis, Mycetozoa, Protista, Puya, SEM, slime mould, taxonomy.

\section{Introduction}

The genus Perichaena (order Trichiales, Myxomycetes) was erected by Fries (1817), based on Perichaena populina (Alb. \& Schwein) Fr., a synonym of Perichaena corticalis (Batsch) Rostaf. (Martin, 1966). The species of the genus Perichaena are mainly characterized by having simple or branched tubular capillitial threads, which are roughened, warted or spiny to

\section{Resumen}

Lado, C., Wrigley de Basanta, D., Estrada-Torres, A., García Carvajal, E., Aguilar, M. \& Hernández-Crespo, J.C. 2009. Descripción de una nueva especie de Perichaena (Myxomycetes) encontrada en zonas áridas de Argentina. Anales Jard. Bot. Madrid 6651: 63-70 (en inglés).

Se describe una nueva especie, Perichaena calongei, que fue encontrada en el desierto de Monte, en las zonas áridas del noroeste de Argentina. Los cuerpos fructíferos se encontraron fructificados en el campo, también se obtuvieron por cultivo en cámara húmeda de plantas recolectadas en las provincias de Catamarca, Jujuy, La Rioja, Salta y San Juan. La combinación de caracteres de la morfología del esporocarpo, de la estructura y tipo de dehiscencia del peridio, y de la ornamentación del capilicio, distinguen esta especie del resto de las conocidas en el género. La morfología de la especie se analizó con un microscopio óptico dotado de contraste interferencial de Nomarski y con un microscopio electrónico de barrido, se incluyen ilustraciones de las estructuras observadas. Se propone una clave dicotómica para la identificación, a nivel mundial, de las especies estipitadas del género Perichaena.

Palabras clave: desierto de Monte, morfogénesis, Mycetozoa, Protista, Puya, MEB, hongos mucilaginosos, taxonomía.

minutely annulate in some species, but not marked with spiral bands (Martin \& al., 1983). The capillitial threads have an irregular outline, are normally not isodiametric, and are generally perforated with pits only visible by SEM.

The last taxonomic revision of this genus was made by Keller (1971), in which he established the limits between different species, and elaborated a key of the 13 
species known then. The taxonomic problems in the group, detailed by Keller in this paper, were later updated by Keller \& Eliasson (1992). Some species of the genus have a wide distribution and are ubiquitous, but others have a very restricted distribution, or are known only from the type locality.

This genus includes 26 species according to Hernández-Crespo \& Lado (2005) and Lado (2008). Six of them were described with stipitate sporocarps. These are Perichaena pulcherrima Petch (Petch, 1909); P. pedata (Lister \& G. Lister) G. Lister ex E. Jahn (Jahn, 1919); P. reticulospora H.W. Keller \& D.R. Reynolds (Keller \& Reynolds, 1971); P. papulosa C.H. Liu \& J.H. Chang (Liu \& al., 2007); P. polygonospora Novozh., Zeml., Schnittler \& S.L. Stephenson and P. heterospinispora Novozh., Zeml., Schnittler \& S.L. Stephenson (Novozhilov \& al., 2008). Another two species originally described as sessile, have been found with short stalks, or with a reduced base that can be interpreted as a very short stalk. These are Perichaena chrysosperma (Curr.) Lister (Lister, 1894), and P. areolata Rammeloo (Rammeloo, 1984a). In addition, Estrada-Torres \& al. (2009), have described another one, P. stipitata Lado, Estrada \& D. Wrigley, thus increasing the number of stipitate species to 9 .

During intensive studies of different arid areas in the Neotropical Region, some stipitate specimens of Perichaena were collected both in the field, and also from moist chamber cultures of native plant material. The combination of the morphology of the sporocarps, the structure and dehiscence of the peridium, and the ornamentation of the capillitium were different from the known species in the genus. A detailed description, illustration and discussion are provided of this material, which we propose here as a new species.

\section{Materials and methods}

The collecting sites pertinent to this paper were located between $23^{\circ} 50^{\prime}-30^{\circ} 10^{\prime}$ South latitude and $65^{\circ} 27^{\prime}-67^{\circ} 48^{\prime}$ West longitude, along the eastern foothills of the Andes. The vegetation was xerophyllous scrubland, where in rocky areas, the rosetteleaved bromeliad Puya spp. predominated.

The studies involved the collection in the field of myxomycetes from known or suspected microhabitats, and removal of substrates for laboratory culture. This paper is based on material obtained from field collections on the dead leaves and moist chamber cultures of leaf bases, of Puya spp. The field collections and the substrate material for moist chamber cultures were made in five states of northwest Argentina (Catamarca, Jujuy, La Rioja, Salta and San Juan) by C. Lado, A. Estrada-Torres and D. Wrigley de Basanta.
Field collections were dried and glued into herbarium boxes in situ. Material for moist chamber culture was air-dried in situ and transported in sealed paper bags. All the localities were geo-referenced using a GPS (Magellan eXplorist 600 Ver. 5.1, Datum WGS84).

The moist chamber cultures were prepared using pieces of dry Puya sp. leaf bases, which were placed on filter paper lining sterile $9 \mathrm{~cm}$ plastic Petri dishes. The cultures were prepared as described in Wrigley de Basanta \& al. (2009). All fruiting bodies of the same species in one culture were regarded as being one collection. All the specimens are deposited in the herbarium MA-Fungi (sub Lado), and the private collection of Diana Wrigley de Basanta (dwb).

All microscope measurements and observations were made with material mounted directly in Hoyer's medium. A microscope with differential interference contrast (DIC) was used to obtain descriptive data and light micrographs. The critical-point drying technique was used for scanning electron microscopy (SEM) preparations, and the SEM analyses and photomicrographs of specimens were made by the Scanning Electron Microscopy Department of the Royal Botanic Garden of Madrid, employing a Hitachi S$3000 \mathrm{~N}$ scanning electron microscope, at $10-15 \mathrm{kV}$. Colour notations in parentheses are from the ISCCNBS Color-Name Charts Illustrated with Centroid Colors (Anon, 1976).

\section{Taxonomic treatment}

Perichaena calongei Lado, D. Wrigley \& Estrada, sp. nov. Figs. 1-3, 5-22

Sporocarpia dispersa, stipitata vel subsessilia. Sporotheca subglobosa, 0,2-0,8 mm diam., flavo-aurantiaca vel fusca. Stipes cylindricus, 0,1-0,35 mm altus. Peridium bistratum; stratum externum coriaceum, depositum granulatae materiae includens; stratum internum membranaceum, ad externo strato valde adbaerens; in frustula polygona debiscente. Capillitium flavum, tubulis 2-4 um diam., cum ramis, non regulariter ornatum spinis, granulis vel reticulis. Sporae liberae, flavo-aurantiacae in massa, flavae luce transmissa, 10-13,5 um diam., verrucosae.

Sporophores sporocarpic, scattered or in small groups of 2-4 sporocarps, shortly stalked or subsessile. Sporotheca sub-globose, 0.2-0.8 mm diam., orange yellow (67. brill. OY - 72. d. OY) to dark brown (78. d. y Br), often with dark lines marking the edges of peridial plates (Figs. 1-3, 5). Hypothallus membranous, brownish, discoid, individual under each sporocarp. Stalk cylindrical, 0.1-0.35 mm in height, without calcium deposits, dark brown (59. d. 

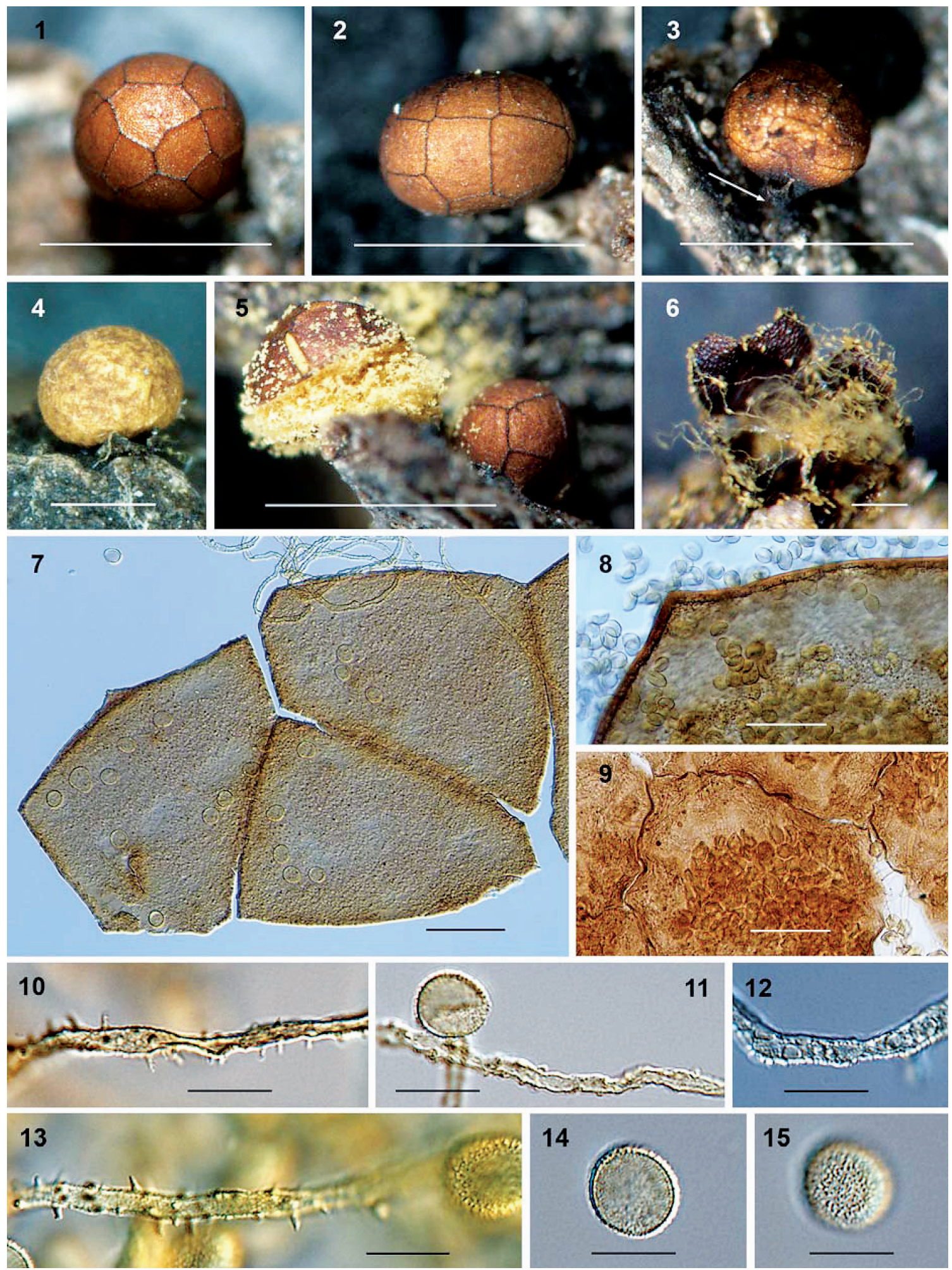

Figs. 1-15. 1-3, 5-15, Perichaena calongei. 1, 2, Sporocarps showing peridial plates. 3, Sporocarp showing dark stalk (arrow). 4, Perichaena areolata. Sporocarp. 5, Dehisced sporocarp showing the mass of spores and closed sporocarp. 6, Dehisced sporocarp showing petaloid calyculus-like base. 7, Polygonal plates of the peridium by transmitted light showing the dark borders. 8, Detail of dark edge of peridial plate by LM. 9, Detail of peridial plates by LM of a less mature sporocarp. 10, 13, Capillitial tubule ornamented with spines and granules. 11, Capillitial tubule ornamented with short spines. 12, Capillitial tubule ornamented with a pitted reticulum. 14, 15, Spores warted by LM. [1-3) dwb 2857 (holotype, MA-Fungi 78697); 4) GENT 10581 (typus); 5, 8, 10, 13-15) dwb 2833; 6) Lado 18242 (MA-Fungi 78680); 7, 12) Lado 18241 (MA-Fungi 78679); 9) dwb 2838; 11) Lado 18322 (MA-Fungi 78687)]. Bar: 1-3, 5 = 1 mm; $4=0.5 \mathrm{~mm} ; 6=100 \mu \mathrm{m} ; 7-9=50 \mu \mathrm{m} ; 10-15=10 \mu \mathrm{m}$. 

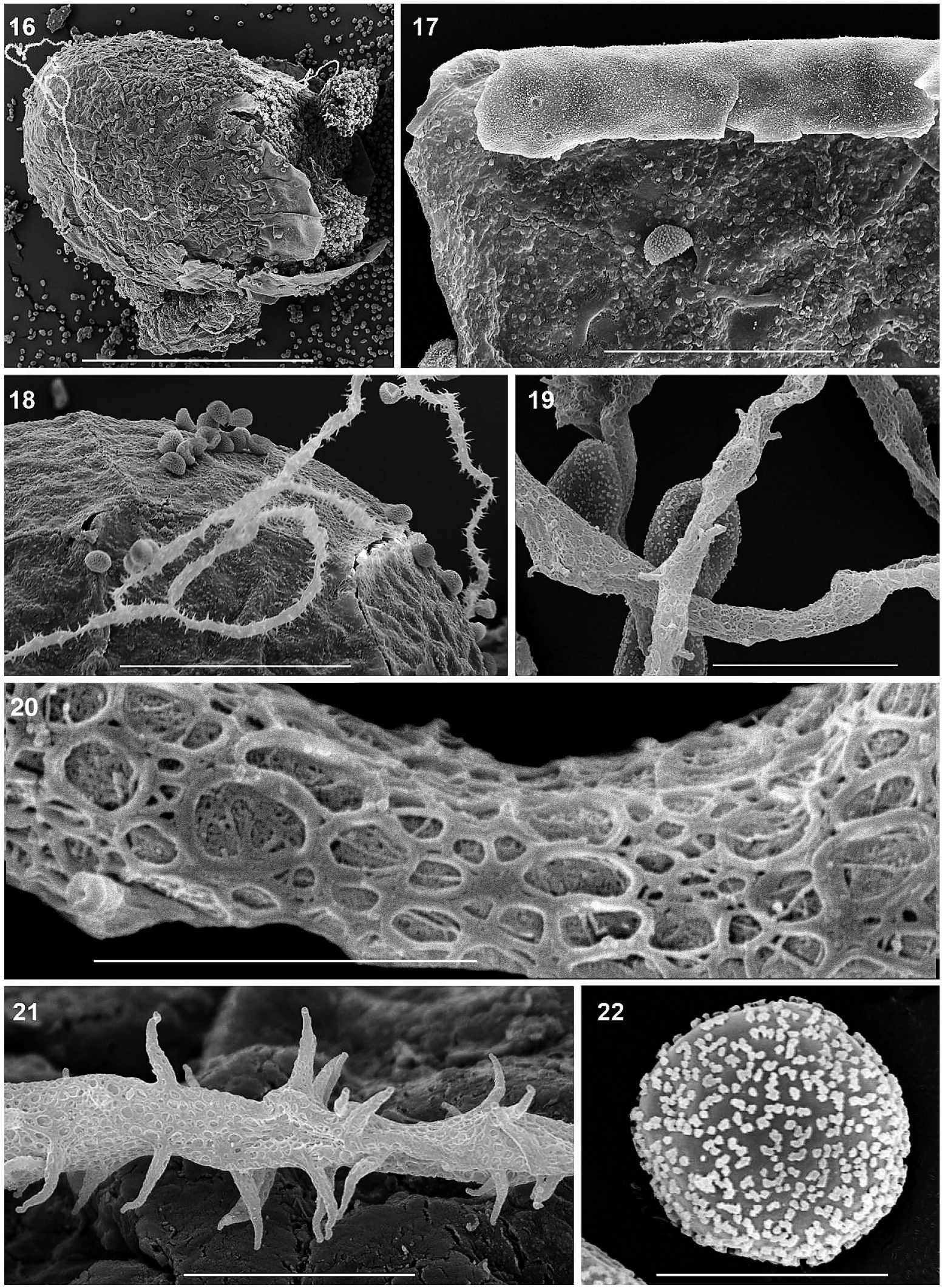

Figs. 16-22. Perichaena calongei by SEM. 16, Whole sporocarp with short stipe. 17, Detail of edge of a peridial plate showing the almost smooth inner surface of the inner layer. 18, Detail of the sporocarp surface showing peridial plates. 19, Capillitial tubules showing sections with short spines and with no spines. 20, Detail of a capillitial tubule showing double reticulum. 21, Spiny section of a capillitial tubule. 22, Spore with flattened warts. [16-22) dwb 2857 (holotype, MA-Fungi 78697)]. Bar: $16=500 \mu \mathrm{m} ; 17=50 \mu \mathrm{m}$; $18=100 \mu \mathrm{m} ; 19=20 \mu \mathrm{m} ; 20=5 \mu \mathrm{m} ; 21,22=10 \mu \mathrm{m}$. 
Br) to blackish (Fig. 3), filled with refuse matter, with a roughened surface. Peridium double, outer layer coriaceous, with granular material, yellow (84. s. Y - 88. d. Y), to deep orange yellow (69. deep. OY - 72. d. OY) or greyish yellow (90. gy. Y) by transmitted light; inner layer membranous, yellowish, strongly adhered to the external layer, with the inner surface almost smooth by SEM (Fig. 17); dehiscing into polygonal plates (Figs. 5, 18), leaving a petaloid calyculus-like base (Fig. 6); peridial plates of 4-6 sides (Figs. 1,7), often with a dark smooth border which is sometimes revolute (Figs. 8, 17). Columella absent. Capillitium tubular, tubules of irregular diameter, 2-4 $\mu \mathrm{m}$ diam., by SEM perforated, greyish yellow (90 gy. Y) to brilliant yellow (83. brill. Y) by LM, branched, forming a lax net, with few free ends, ornamentation very irregular, some tubules with spines 0.5-3 $\mu \mathrm{m}$ long (Figs. 1819,21 ), others with granules, or a pitted reticulum (Fig. 20), the pits up to $3 \mu \mathrm{m}$ diam. and then visible at high magnification by LM (Fig. 12), with a second faint reticulum below only visible by SEM (Fig. 20); the tubules with triangular expansions up to $15 \mu \mathrm{m}$ wide at the junction of the branches, and sometimes with intercalated or terminal sub-globose, ellipsoid or fusiform expansions, 7.5-16 × 10-16 $\mu \mathrm{m}$. Spores free, orange yellow (67. brill. OY) in mass, light green yellow (101. 1. g Y) to brilliant yellow (83. brill. Y) by LM, sub-globose, 10-13.5 $\mu \mathrm{m}$ diam., densely warted, with flattened warts by SEM (Fig. 22). Plasmodium unknown.

Holotype: ARGENTINA. Salta: Molinos, Seclan-

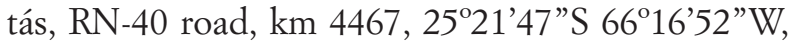
$2238 \pm 6$ m, dead leaf base of Puya sp., 29-III-2007, leg. C. Lado, A. Estrada and D. Wrigley de Basanta, dwb 2857 (MA-Fungi 78697).

Etymology: Named after Francisco de Diego Calonge, a renowned Spanish mycologist.

Habitat: Dead leaves of Puya spp.

Known distribution: northwest Argentina (states of Jujuy, Salta, Catamarca. La Rioja and San Juan). Possibly occurring in other areas of South America, following the distribution of species of the plant genus Puya.

\section{Other specimens examined}

ARGENTINA. Catamarca: Belén, RN-40 road to Hualfín, at 4 $\mathrm{km}$ from Belén, $27^{\circ} 36^{\prime} 55^{\prime}$ "S $67^{\circ} 01^{\prime} 06^{\prime}$ 'W, $1305 \pm 6 \mathrm{~m}$, leaves of Puya sp., 27-XI-2006, Lado 18300 (MA-Fungi 78682), Lado 18301 (MA-Fungi 78683), Lado 18307 (MA-Fungi 78684). Belén, RN-40 road to Hualfín, at $7 \mathrm{~km}$ from Belén, Morro de los Cóndores Nature Reserve, 2734'13"S 6700'10"W, $1308 \pm 16$ m, leaves of Puya sp., 27-XI-2006, Lado 18318 (MA-Fungi 78685), Lado 18321 (MAFungi 78686), Lado 18322 (MA-Fungi 78687), Lado 18330 (MAFungi 78688). Tinogasta, RN-60 road, km 1317, at $10 \mathrm{~km}$ from La
Puntilla, 2806'13"S 67³0'52"W, $1184 \mathrm{~m} \pm 8 \mathrm{~m}$, dead leaf base of Puya sp., 18-III-2007, dwb 2838 (mc, pH 7.1). Tinogasta, Costa de Reyes, RP-3 road, 28¹6'18”S 67³8'51”W, $1437 \mathrm{~m} \pm 7 \mathrm{~m}$, dead leaf bases of Puya sp, 5-VII-2007, dwb 3009 (mc, pH 7.4); 29-XI-2007, leaves of Puya sp., Lado 18372 (MA-Fungi 78689). Jujuy: Tumbaya, Volcán, Huajra, 2352'12”S 65²7’50”W, $2112 \mathrm{~m} \pm 8 \mathrm{~m}$, dead leaf bases of Puya sp., 11-X-2007, dwb 2957 (mc, pH 6.9). La Rioja: Independencia, Talampaya National Park, RP-26 road, km 99,

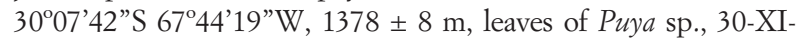
2006, Lado 18420 (MA-Fungi 78690). Salta: Molinos, Seclantás, RN-40 road, km 4467, 2521'47”S 66'16'52”W, $2238 \pm 6$ m, leaves of Puya sp., 25-XI-2006, Lado 18236 (MA-Fungi 78678), Lado 18241 (MA-Fungi 78679), Lado 18242 (MA-Fungi 78680), Lado 18247 (MA-Fungi 78681); dead leaf base of Puya sp., 23-III-07, dwb 2833 (mc, pH 7), 29-III-2007, dwb 2857 (mc, pH 7) (holotype), 4-IV-2007, dwb 2865 (mc, pH 7.1). San Juan: Valle Fértil, Ischigualasto Provincial Park, RP-510 road to the Park, km 104, $30^{\circ} 10^{\prime} 44^{\prime \prime} \mathrm{S} 67^{\circ} 48^{\prime} 56^{\prime} \mathrm{W}, 1374 \mathrm{~m} \pm 12 \mathrm{~m}$, dead leaf base of Puya sp., 23-III-2007, dwb 2850 (mc, pH 7.1), 14-IV-2007, dwb 2873 (mc, pH 6.9). San José de Jáchal, San Roque, RN-40 road, km 3619, 30²1'03"S 68'38'07"W, 1054 m, 8-III-2007, leaves of Puya sp., Lado 18709 (MA-Fungi 78691), Lado 18710 (MA-Fungi 78692), Lado 18716 (MA-Fungi 78693). Ullum, RP-436 road, at $16.2 \mathrm{~km}$ northeast of the junction with RN-40 road, Termas de Talacasto,

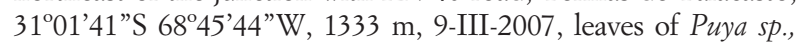
Lado 18723 (MA-Fungi 78694).

Ophiotheca wrightii Berk \& M.A. Curtis, holotype K, Cuba, on wood, Coll. C. Wright 673 [A.L. 1713; ex herb. Berkeley].

Perichaena areolata Rammeloo, typus GENT, Rwanda, Mukavura-vulkaan (W. flank), 3500 m, on Dendrosenecio bladeren, 1/8/1974, Coll. Van der Veken, nr. 10581.

\section{Discussion}

Apart from the stalk, which in the genus Perichaena is not common, the most obvious character of this new Perichaena is the dark-edged polygonal peridial plates (Figs. 1-3, 5, 7) and the form of petaloid dehiscence of the peridium (Fig. 6). In addition, the capillitial tubules, with varied ornamentation from spiny to granulate and reticulate distinguish it from other species in the genus.

The spiny capillitium is similar to that of Perichaena chrysosperma, in which species some short-stalked sporocarps have been described, but the dehiscence of the peridium is irregular or longitudinal in this species (Rammeloo, 1984a), not by polygonal plates, and not leaving a petaloid calyculus-like base as in $P$. calongei. The capillitial spines in $P$. calongei are also shorter (0.5-3 $\mu \mathrm{m}$ long vs. 2.9-5.5 $\mu \mathrm{m}$ long in P. chrysosperma), less densely and not uniformly distributed, intercalated with many long stretches of totally spineless capillitium. In addition, the capillitium of P. chrysosperma has a pitted surface (Rammeloo, 1984a), and lacks the double reticulum of $P$. calongei by SEM (Figs. 20, 21). 
The SEM illustrations (Rammeloo, 1984a) of the type of Ophiotheca wrightii Berk. \& Curt., included in the species Perichaena chrysosperma, show capillitium with a reticulate surface. We examined the type specimen of O. wrightii preserved at $\mathrm{K}$ (Wright 673), which has definite sessile, flexuous plasmodiocarps, not sporocarps like $P$. calongei. The type material of O. wrightii has no peridial plates, nor outer markings on the peridium, unlike P. calongei, and spines 2.5-4 $\mu \mathrm{m}$ long, twice the diameter of the capillitial tubules (0.5-3 $\mu \mathrm{m}$ in P. calongei). By SEM, O. wrightii also has a very densely verrucose inner surface of the peridium (Rammeloo, 1984a), while P. calongei has an almost smooth inner surface, only faintly stippled by SEM (Fig. 17).

Other Perichaena species with short non-calcareous stalks are $P$. areolata Rammeloo, $P$. pedata and $P$. reticulospora. We examined the type specimen of Perichaena areolata (GENT 10581) which contains about 15 sporocarps either sessile or shortly stipitate. The closed sporocarps have a mottled peridial surface (Fig. 4) but no sign of peridial plates. The open sporocarps show irregular dehiscence. Perichaena calongei has a peridium divided into plates with a darker border (Figs. 1-3), and the open sporocarps show dehiscence by these plates (Figs 5-6). Perichaena areolata has a dense regular papillate ornamentation on the inner surface of the peridium by SEM (Rammeloo, 1984b) whereas $P$. calonge $i$ has an almost smooth inner surface to the peridium by SEM (Fig. 17). The ornamentation of the capillitial tubules is also different, composed of "spine-like excrecences up to $1.8 \mu \mathrm{m}$ high" (Rammeloo, 1984a), which are regularly distributed in $P$. areolata, and varied ornamentation from spines, 0.5-3 $\mu \mathrm{m}$ long (Figs. 10, 13, 18, 19, 21), to granules (Fig. 11), with a pitted double reticulum (Figs. 12, 20), in P. calongei. The colour of the sporocarps is also different, a light brown to yellow in P. aereolata (Fig. 4) and dark brown to orange yellow in P. calongei (Figs. 1-3). Perichaena pedata is distinguished from $P$. calongei by the single vs. double peridium, by the ornamentation of the interior of the peridium, marked with dense verrucae by LM, short rounded low ridges in an incomplete network and with numerous verrucate elements by SEM (Rammeloo, 1984b), almost smooth in P. calongei. The capillitial tubules of $P$. pedata does not have a reticulate surface like that of $P$. calongei (Fig. 20), but has papilla-like excrescences (Rammeloo, 1984b) regularly distributed. Perichaena reticulospora has a banded-reticulate ornamentation on the spores (Keller and Reynolds, 1971), not warted like P. calongei.

Perichaena stipitata is clearly distinguishable by its white, calcareous stalk, and the single peridium
(Estrada-Torres \& al., 2009). Any specimens with limeless stalks, can be distinguished from $P$. calongei by the smooth unmarked surface of the sporotheca, the bright yellow colour of the sporotheca, the large perforations in the capillitial tubules with no reticulum and no spines, and the ocellate markings on the inside of the peridium.

More than a third of the known species of the genus Perichaena are stipitate, or occasionally have stalks, and half of these have been described in the last two years. In order to aid in the identification of these stipitate species a key has been proposed below, using characters from their original published descriptions as well as our own observations.

\section{Key to the Perichaena SPECIES}

1. Spores polygonal

P. polygonospora

2. Spores reticulate .................................. P. reticulospora

2. Spores with different ornamentation but not reticulate ..... 3

3. Spores ornamented with scattered, pyramid-like spines, around $1 \mu \mathrm{m}$ high ........................ P. heterospinispora

3. Spores densely ornamented with warts or spinules, less than $0.5 \mu \mathrm{m}$ high

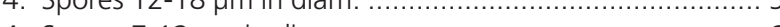

4. Spores $7-12 \mu \mathrm{m}$ in diam. ...................................... 6

5. Stalk calcareous, white, spores 12-15 $\mu \mathrm{m}$ diam.

P. stipitata

5. Stalk not calcareous, brown or red brown, spores 14.5-18 um diam.

P. pulcherrima

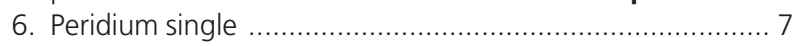

6. Peridium double ................................................... 8

7. Sporotheca with an apical protuberance. Dehiscing leaving a disk-like basal part ....................................... P. papulosa

7. Sporotheca without an apical protuberance. Dehiscence irregular ........................................................... pedata

8. Fructifications plasmodiocarpic to sessile sporocarps, occasionally mixed with short-stalked sporocarps. Capillitial tubules with spines, 2.9-5.5 $\mu \mathrm{m}$ long

P. chrysosperma

8. Fructifications not plasmodiocarpic, the sporocarps stipitate to sub-sessile. Capillitial tubules with spines up to $3 \mu \mathrm{m}$ long .....

9. Peridium marked with dark lines, dehiscence along plates, capillitial tubules with spines, granules (Fig. 11) or a pitted reticulum

P. calongei

9. Peridium not marked with dark lines, dehiscence not along plates, capillitial tubules with regularly distributed spine-like excrecences

P. areolata

In moist chamber culture the new species appeared properly matured, after a mean incubation period of 25 days, in 8 out of the 33 cultures $(24 \%)$ set up with the dead leaf bases of Puya species from Argentina. Three more collections were immature. The mean $\mathrm{pH}$ of the substrate producing this species in moist chamber culture, at 24 hours, was almost neutral (7.06). The bromeliad Puya grows on the ground in dense patches on the drier rocky slopes of these arid areas in Argenti- 


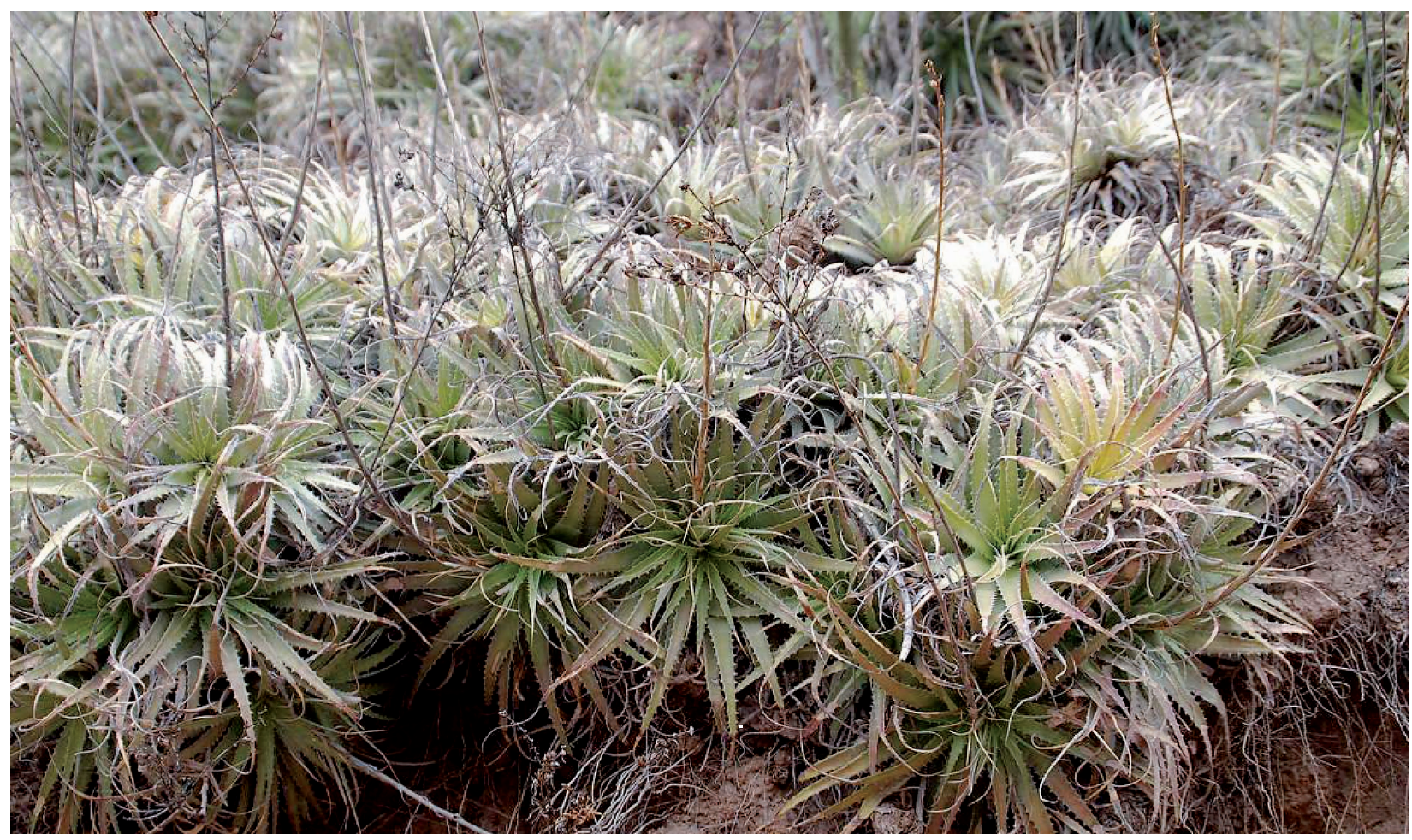

Fig. 23. A species of the bromeliad genus Puya showing the dead leaves that serve as a substrate for Perichaena calongei.

na (Fig. 23). It has proved to be an excellent substrate for myxomycetes as cultures of the leaf bases have been over $94 \%$ positive for myxomycete fruiting bodies or plasmodia. No other substrate, of the more than 100 moist chamber cultures, prepared with native plant remains from the same areas produced this species. It therefore appears to have microhabitat requirements found so far only in this plant genus.

In the field the tiny sporocarps were found among the dead leaves at the base of the plant rosettes, where some moisture still remained. In moist chamber culture, as well as in the field, the sporocarps were scattered, often mixed on the same piece of substrate with other Perichaena species and myxomycetes of different genera such as Cribraria, Arcyria, and a newly described Didymium (Wrigley de Basanta \& al., 2009).

The distinct morphological characters of Perichaena calongei were constant in both field and moist chamber collections. It was collected on several occasions over two years in five different states of Argentina and is thus described as a new species.

\section{Acknowledgements}

This research has been supported by the Ministry of Science and Innovation of Spain (grant CGL2005-00320/BOS and CGL2008-00720/BOS). We are very grateful to Fr. J. Bozonnet for his comments on the Latin diagnosis.

\section{References}

Anonymous. 1976. ISCC-NBS Color-Name Charts Illustrated with Centroid Colors. Inter-Society Color Council. National Bureau of Standards. Washington.

Estrada-Torres, A., Wrigley de Basanta, D., Conde, E. \& Lado, C. 2009. Myxomycetes associated with dryland ecosystems of the Tehuacán-Cuicatlán Valley Biosphere Reserve, Mexico. Fungal Diversity 36: 17-56.

Fries, E.M. 1817. Symbolae gasteromycorum ad illustrandum floram suecicam. Lund.

Hernández-Crespo, J.C. \& Lado, C. (2005). An on-line nomenclatural information system of Eumycetozoa. www.nomen. eumycetozoa.com (10-XI-2008).

Jahn, E. 1919. Myxomycetenstudien.9. Bemerkungen über einige seltene oder neue Arten. Berichte der Deutschen Botanischen Gesellschaft 36: 660-669.

Keller, H.W. 1971. The genus Perichaena (Myxomycetes): a taxonomic and cultural study. Univ. Iowa. Iowa (Ph. D. Dissertation).

Keller, H.W. \& Eliasson, U.H. 1992. Taxonomic evaluation of Perichaena depressa and P. quadrata based on controlled cultivation, with additional observations on the genus. Mycological Research 96(12): 1085-1097.

Keller, H.W. \& Reynolds, D.R. 1971. A new Perichaena with reticulate spores. Mycologia 63(2): 405-410.

Lado, C. 2008. Eumycetozoa.com: nomenclatural database of Eumycetozoa (Myxomycota) (Oct 2007 version). In: Bisby, F.A.\& al. (eds.), Species 2000 E ITIS Catalogue of Life: 2008 Annual Checklist. CD-ROM; Species 2000: Reading, U.K.

Lister A. 1894. A monograph of the Mycetozoa. $1^{a}$ ed. Printed by order of the Trustees. London.

Liu, C.H., Chang, J.H. \& Yang, F.H. 2007. Myxomycetes genera Perichaena and Trichia in Taiwan. Botanical Studies 48: 91-96. 
Martin, G.W. 1966. The genera of Myxomycetes. Studies in Natural History; Iowa University 20(8): 3-32.

Martin, G.W., Alexopoulos, C.J. \& Farr, M.L. 1983. The Genera of Myxomycetes. University of Iowa Press. Iowa.

Novozhilov, Y.K., Zemlyanskaya, I.V., Schnittler, M. \& Stephenson, S.L. 2008. Two new species of Perichaena (Myxomycetes) from arid areas of Russia and Kazakhstan. Mycologia 100(5): 816-822.

Petch, T. 1909. New Ceylon Fungi. Annals of the Royal Botanic Garden (Peradeniya) 4(5): 299-307.

Rammeloo, J. 1984a. Icones Mycologicae 35-54. Nationale Plantentuin van België. Meise.
Rammeloo, J. 1984b. Icones Mycologicae 55-74. Nationale Plantentuin van België. Meise.

Wrigley de Basanta, D., Lado, C. \& Estrada-Torres, A. 2008. Morphology and life cycle of a new species of Didymium (Myxomycetes) from arid areas of Mexico. Mycologia 100(6): 921-929.

Wrigley de Basanta, D., Lado, C., Estrada-Torres, A. \& Stephenson, S.L. 2009. Description and life cycle of a new Didymium (Myxomycetes) from arid areas of Argentina and Chile. Mycologia 101(5): 707-716.

Received: 3-III-2009

Accepted: 7-IV-2009 